\title{
MOŽNOSTI STAVEBNÉHO PREPOJENIA BRATISLAVSKÉHO LETISKA K SIETI ŽSR
}

\section{OPTIONS OF BUILDING CONNECTION OF BRATISLAVA AIRPORT TO ŽSR NETWORK}

\author{
Zdenka Bulková1, ${ }^{*}$, Vladislav Zitrický1 ${ }^{1}$ Jozef Gašparík ${ }^{1}$
}

\begin{abstract}
Abstrakt
Kol'ajová doprava v okolí Bratislavského letiska funguje len pre účely nákladnej prepravy primárne v podobe dovozu pohonných látok, čomu je uspôsobená aj daná infraštruktúra. Potenciál Bratislavského letiska M. R. Štefánika v súčasnosti nie je vyčerpaný, avšak možnosti prístupu k tomuto letisku sú značne vymedzené stupňom rozvinutia jednotlivých druhov infraštruktúry. Železničná infraštruktúra, ktorá $v$ súčasnosti slúži potrebám letiska M. R. Štefánika existuje v podobe železničnej vlečky zaústenej do železničnej siete odbočkou Letisko na neelektrifikovanú jednokol'ajnú trat' smerujúcu do železničnej stanice Podunajské Biskupice. S využitím pre účely osobnej dopravy sa v súčasnej podobe privel'mi nepočíta najmä pre vzdialenost' od terminálu letiska, pričom výhodou tiež nie je ani zaústenie do železničnej siete. Článok sa zaoberá možnost'ami napojenia bratislavského letiska k sieti ŽSR. Základom návrhu napojenia bratislavského letiska vhodnou infraštruktúrou k sieti ŽSR v rámci železničnej osobnej dopravy je stanovenie vhodného prestupného miesta. Jednou z logických priorít je umiestnenie prestupného miesta čo najbližšie k terminálu leteckej dopravy bratislavského letiska v rámci priestorových možností a technických podmienok.
\end{abstract}

Klíčová slova prestupné miesta, železničná doprava, letecká doprava, železničná siet'

Summary Rail transport in the vicinity of Bratislava Airport works only for the purpose of freight transport. It is primarily in the form of fuel imports, to which the given infrastructure is also adapted. At present, the potential of Bratislava Airport M. R. Štefánik is not spent. However, the possibilities of access to this airport are considerably limited by the degree of development of individual types of infrastructure. The railway infrastructure that currently serves the needs of M. R. Štefánik Airport exists in the form of a railway siding. It opens into the railway network by turning the Airport onto a non-electrified singletrack line, which leads to the railway station Podunajské Biskupice. At present, not much is expected to be used for passenger transport purposes. This is mainly the distance from the airport terminal, while the advantage is not even the mouth of the railway network. The article deals with the possibilities of connecting Bratislava Airport to the ŽSR network. The basis for the proposal to connect Bratislava Airport with a suitable infrastructure to the ŽSR network within the framework of railway passenger transport is the determination of a suitable transfer point. One of the logical priorities is to place the transfer point as close as possible to the air transport terminal of Bratislava Airport within the space possibilities and technical conditions.

Keywords $\quad$ transfer points, railway transport, air transport, railway network

\footnotetext{
1 Žilinská univerzita v Žiline, Fakulta prevádzky a ekonomiky dopravy a spojov, Katedra železničnej dopravy, Univerzitná 8215/1, 01026 Žilina, Slovensko

* korešpondenčný autor: zdenka.bulkova@fpedas.uniza.sk
} 


\section{1 ÚVOD}

Súčasný charakter železničnej infraštruktúry v okolí letiska BTS je analyzovaný ako nevyhovujúci. Aktuálna podoba železničnej infraštruktúry sledovaného územia nie je uspôsobená na vytvorenie vhodného miesta určeného na nástup a výstup cestujúcich v primeranej vzdialenosti od terminálu letiska BTS prekonatel'nej pešou chôdzou tak, aby nebolo potrebné na presun medzi týmito miestami využit' d'alší druh dopravy.

Opodstatneným krokom je analýza možností napojenia letiska BTS na železničnú siet' ŽSR a spracovat' návrh trasovania príslušnej infraštruktúry, ktorá bude vyhovujúca pre účely osobnej dopravy $\mathrm{s}$ primeranou mierou komfortu, kvality a bezpečnosti. Tento krok musí prebiehat' najmä v súlade so Zákonom o dráhach 513/2009 Z. z. a Vyhláškou 350/2010 Z. z. o stavebnom poriadku dráh. Pre účel návrhu treba dbat' na podmienky uvedené v Leteckom zákone 143/1998 Z. z., čím budú splnené podmienky pre kompletizáciu samotného návrhu. (Čechovič, et. al., 2020)

\section{CHARAKTERISTIKA ŽELEZNIČNEJ SIETE SR A BRATISLAVSKÉHO LETISKA}

Súčasná železničná infraštruktúra na území hlavného mesta Slovenskej republiky je koncipovaná ako významný dopravný uzol niekol'kých navzájom prepojených európsky dôležitých tratí zaradených tiež do sietí TEN, AGC a AGTC. (Zitrický, et. al., 2020)

Nadregionálne magistrálne železničné trate označené podl'a úsekov na Slovenskom území z tabuliek trat'ových pomerov (d’alej TTP) ŽSR prechádzajú oblast'ou radiálne v smeroch (BSK, 2012):

- 126 A : Bratislava - Brno - Praha - Drážd’any - Berlín - Hannover,

- 125 A: Bratislava - Žilina - Čadca - Zwardoň - Varšava - Gdaňsk,

- 120 A: Bratislava-Štúrovo-Budapešt' - Belehrad - Istanbul - (Thessaloniky).

Železničný uzol Bratislava, štandardného rozchodu kol’ají 1435 mm tvoria jednotlivé úseky súhrnnej dížky 100,7 km, z ktorých je 49,5 km dvojkol’ajných a ostatnú dížku tvoria jednokol’ajné úseky. Z celkovej dížky trat'ových úsekov je 86,6 km elektrifikovaných jednofázovou striedavou napájacou sústavou $25 \mathrm{kV}$ a 50 Hz. (Černá, et. al., 2018)

Železničná infraštruktúra, ktorá v súčasnosti slúži potrebám letiska M.R. Štefánika, existuje v podobe železničnej vlečky zaústenej do železničnej siete odbočkou Letisko, podl'a obrázku 1, na neelektrifikovanú jednokolajnú trat' smerujúcu do ŽST Podunajské Biskupice. Táto vlečka slúži na prísun ložených vozňov s ropnými produktmi, predovšetkým leteckým palivom a následný odsun prázdnych vozňov. (Mako, et. al., 2021)

S využitím pre účely osobnej dopravy sa v súčasnej podobe nepočíta najmä pre účel na ktorý je prispôsobená a využívaná s okolitými skladmi leteckých pohonných hmôt a tiež pre vzdialenost' od terminálu letiska, pričom výhodou tiež nie je ani zaústenie do železničnej siete. Obrázok 1 znázorňuje súčasné napojenie vlečky letiska k sieti ŽSR.

Civilné letisko M. R. Štefánika - Airport Bratislava, a. s. (d’alej BTS), s nepretržitou 24 hodinovou prevádzkou vzniklo v roku 1951 a je situované pri meste Bratislava s vzdialenost'ou od samotného centra mesta 9 kilometrov severovýchodne. 


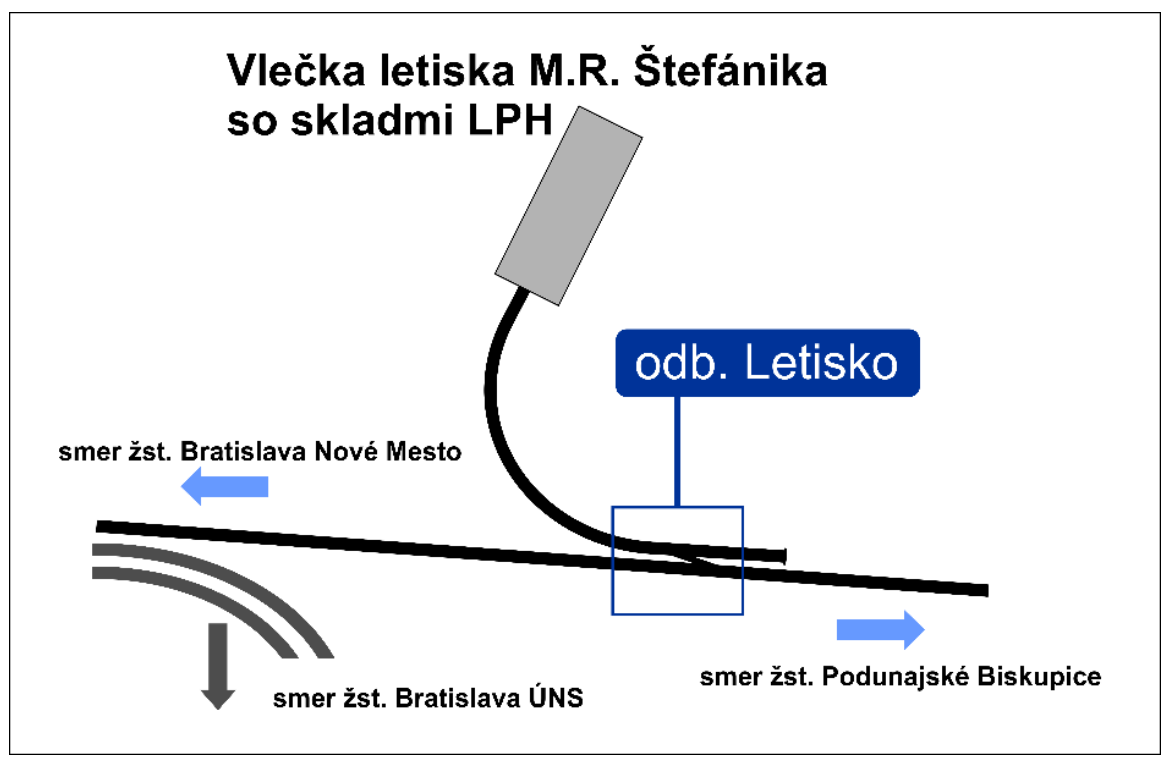

Obr. 1 Zapojenie vlečky letiska M. R. Štefánika do železničnej siete; zdroj: (Remeň, 2019)

V súčasnosti sú v prevádzke dve vzletové a pristávacie dráhy s betónovým povrchom (obrázok 2). Hlavná dráha s dížkou 2950 metrov a šírkou 45 metrov je značená údajmi 13/31, ktoré stanovujú smer dráhy podl'a magnetického azimutu. Vedl'ajšia vzletová a tiež pristávacia dráha 04/22 má dĺžku 2900 metrov a šírku 60 metrov. Bod pretnutia dráh je vzdialený 904 metrov od prahu dráhy 13 a 1428 metrov od prahu dráhy 04. Odbavovacia plocha letiska s rozlohou 143-tisíc $\mathrm{m}^{2}$ má vyznačených 33 stojísk pre lietadlá. (BTS, 2018)

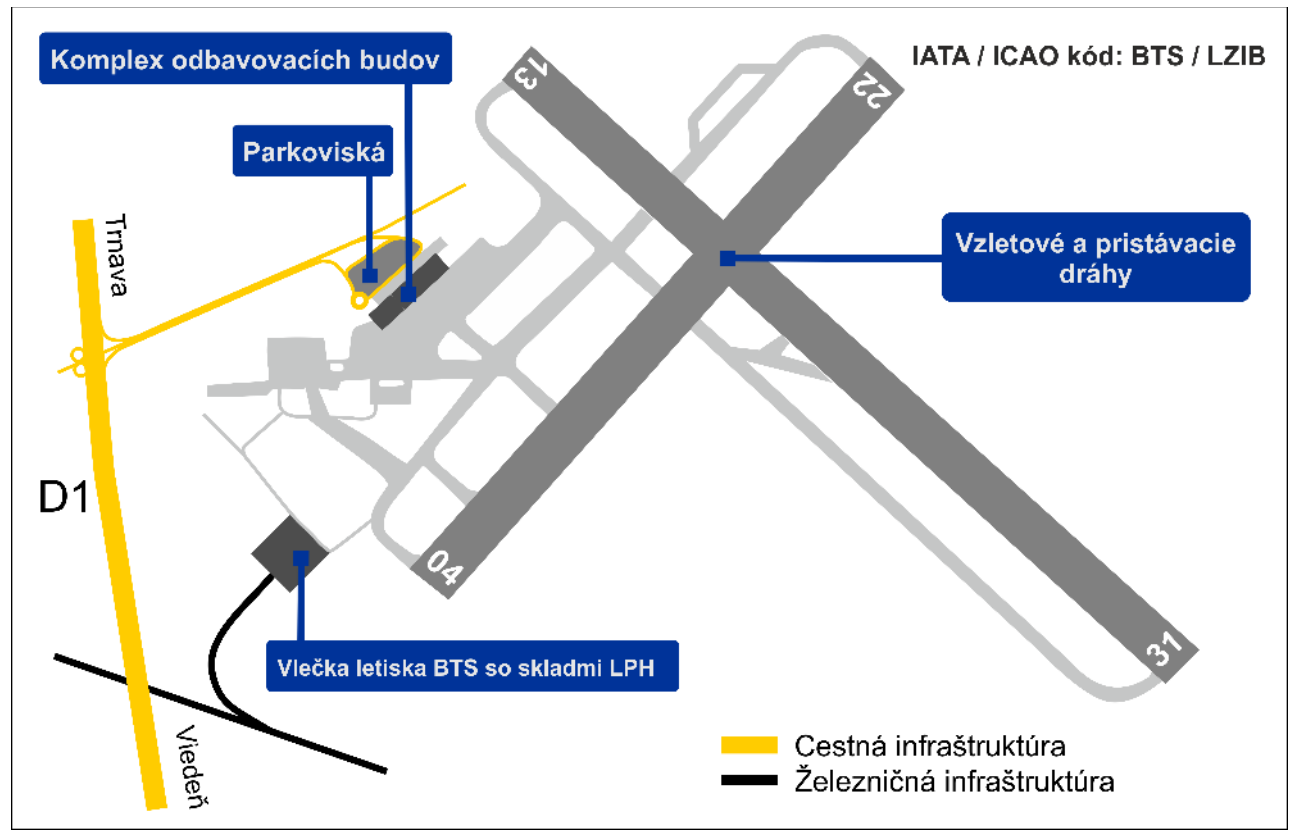

Obr. 2 Schematické znázornenie usporiadania letiska BTS; zdroj: (Remeň, 2019)

Umiestnenie komplexu troch na seba nadväzujúcich odbavovacích hál terminálu je schematicky znázornený na obrázku 2 a jeho celková rozloha je $48545 \mathrm{~m} 2 \mathrm{~s}$ predpokladanou kapacitou 5 miliónov odbavených cestujúcich za rok. Obrázok 2 vykresl'uje tiež existujúcu infraštruktúru v okolí letiska, pričom je demonštrovaná rozdielna vzdialenost' umiestnenia už spomínanej železničnej infraštruktúry a tiež cestnej infraštruktúry k samotnému odbavovaciemu terminálu. Medzi terminálom a parkoviskami P1 a P2, spomenutými vyššie, sú umiestnené tiež parkovacie sloty pre taxislužby a autobusovú dopravu. (BTS, 2018) 


\section{UMIESTNENIE PRESTUPNÉHO MIESTA MEDZI LETISKOM BTS A ŽELEZNICOU}

Základom pre návrh možností napojenia letiska BTS vhodnou infraštruktúrou na siet' ŽSR v rámci osobnej dopravy je stanovenie vhodného prestupného miesta. Jednou z logických priorít tohto návrhu je umiestnenie prestupného miesta čo najbližšie k terminálu leteckej dopravy letiska BTS s prihliadnutím na priestorové možnosti a technické podmienky.

Základné dispozičné možností umiestnenia železničnej infraštruktúry znázorňuje obrázok $3 \mathrm{~s}$ mapou územia v okolí komplexu odbavovacích budov letiska BTS spracovávanej v mierke 1 : 5 000. Znázornený tu je priestorový rádius centrovaný do roviny vchodov terminálu letiska. Tento rádius tvoria dve vzdialenostné pásma 250 a $500 \mathrm{~m}$, pričom znázornená rovina predeluje daný rádius a polkruh, ktorý vznikol prirodzene za touto rovinou a nie je možné ho zaradit' k územiu, na ktorom je možné umiestnit' železničnú infraštruktúru. Prvé pásmo 250 metrov ohraničuje maximálnu vzdialenost' pri plánovaní TIOP prekonávanú chôdzou medzi nástupišt'om a miestom prestupu na iný druh dopravy, pričom štandardom je vzdialenost' približne 50 metrov. Pásmo do 500 metrov bolo zvolené v rámci súčasnej priestorovej situácie v okolí letiska BTS s dosahom na vol'né a nezastavané plochy. V tomto prípade by umiestnenie nástupišt’a železničnej dopravy nemalo byt' považované za súčast' TIOP, ale iba ako železničnú zastávku resp. železničnú stanicu v blízkosti letiska. Týmto by však ciel' navrhnút' atraktívne spojenie a podporit' verejnú železničnú dopravu, nemusel byt' dosiahnutý v očakávanom rozsahu. Dôvodom je bezprostredná vzdialenost' pred vstupom do komplexu odbavovacích budov, kde už sú zriadené autobusové zastávky, stojiská taxislužieb a parkoviská IAD.

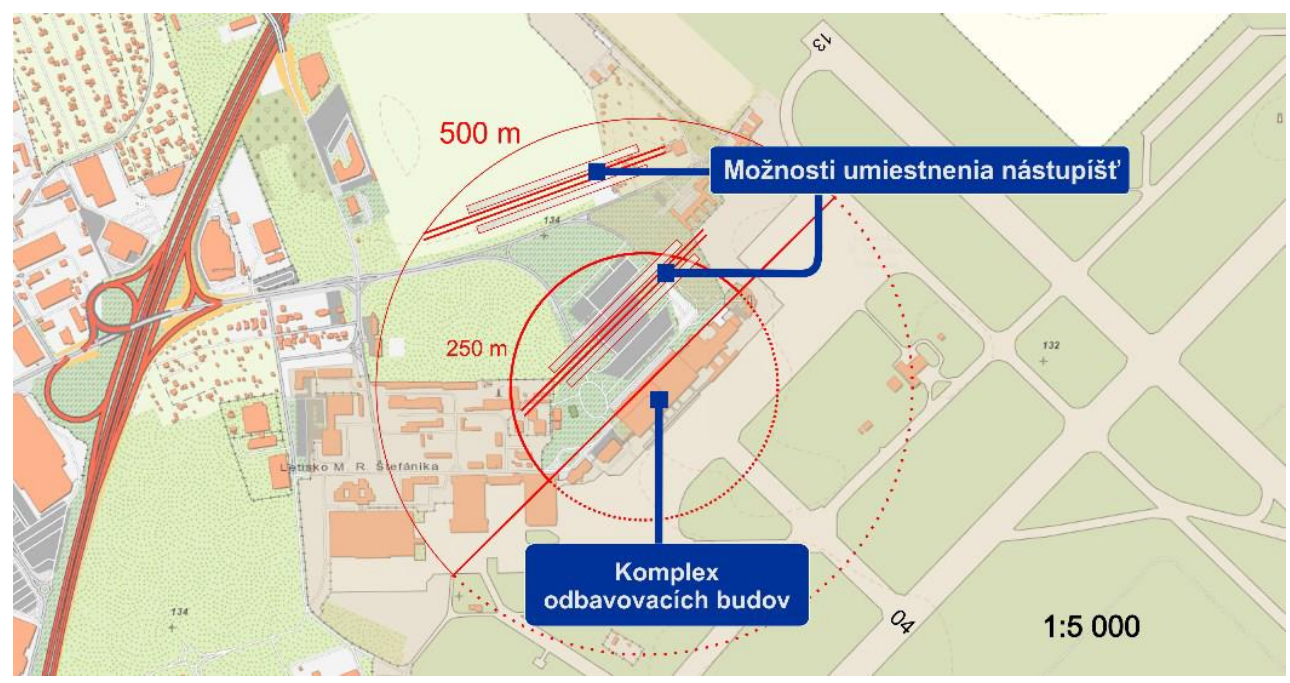

Obr. 3 Priestorový rádius možností umiestnenia prestupného bodu zo ŽD; zdroj: (Remeň, 2019)

Výsledné umiestnenie železničnej stanice, ako súčasti TIOP BTS zahŕňa vyššie uvedené podmienky atraktivity a vzhl'adom na priestorové možnosti ide o podúrovňový variant trasovania železničnej infraštruktúry plánovanej stanice.

Medzi výhody navrhnutého riešenia patrí:

- mimoúrovňové kríženie s komunikáciami v okolí letiska,

- minimálna vzdialenost' k terminálu letiska,

- priame $400 \mathrm{~m}$ dlhé a $550 \mathrm{~mm}$ nad TK vysoké štandardizované nástupištia,

- možnost' híbenia priestoru výkopovými prácami pre umiestnenie nad nezastavaným priestorom (okrem dočasného zrušenia parkoviska),

- lepšie možnosti prepojenia so siet'ou ŽSR úsekmi s vyššou trat'ovou rýchlost'ou,

- terén a podložie v oblasti stavby,

- menší vplyv na ráz krajiny a mesta po dobudovaní. 
Súčasne však dané riešenie prináša aj nevýhody v podobe:

- vyšších stavebných nákladov,

- technologickej náročnosti výstavby v porovnaní s umiestnením na povrchu,

- prevádzkové náklady.

\section{MOŽNOSTI NAPOJENIA TIOP BTS NA SIEŤ ŽSR}

Možnosti napojenia TIOP BTS na existujúcu železničnú infraštruktúru ŽSR sú celkovo tri. Opodstatnené je porovnanie a zváženie ich výhodnosti samostatne, prípadne vo vzájomnej kombinácii. Vhodnými medzistaničnými úsekmi sú podl'a tabuliek trat'ových pomerov ŽSR (d'alej len TTP ŽSR) úseky 120A medzi ŽST Bernolákovo a odbočkou Močiar v oboch smeroch, 127C medzi ŽST Bratislava Nové Mesto - ŽST Bratislava ÚNS tiež v oboch smeroch, a úsek 124A smerom na ŽST Podunajské Biskupice, podobne ako súčasná vlečka na letisko.

\subsection{Napojenie na trat'ový úsek ŽSR 120A}

Plánovaný jednokol'ajný trat'ový úsek $\mathrm{v}$ dížke $3,3 \mathrm{~km} \mathrm{k}$ TIOP BTS, smerovaný z odb. Močiar a elektrifikovaný v celej dížke napájacou napät'ovou sústavou $25 \mathrm{kV}$ a $50 \mathrm{~Hz}$, je napojený na hlavnú trat' ŽSR 120A v kilometri 62,797 pred ŽST Bratislava-Vajnory. Tento úsek je v rámci tohto článku nazvaný BTS A (obrázok 4). Vedie takmer nezastavanou oblast'ou a prekonáva mimoúrovňovo dial'ničný úsek D1 (E75), cestu 1. triedy I/61 a miestnu komunikáciu Vajnorský nadjazd pod úrovňou terénu. Trasovanie je oproti Dopravno-urbanistickej štúdii pôvodného projektu TEN - T 17 napojenia letiska z roku 2009 odlišné, pretože podl'a tejto štúdie mala byt' trasa na trat' ŽSR 120A napojená až za ŽST Bratislava - Vajnory.

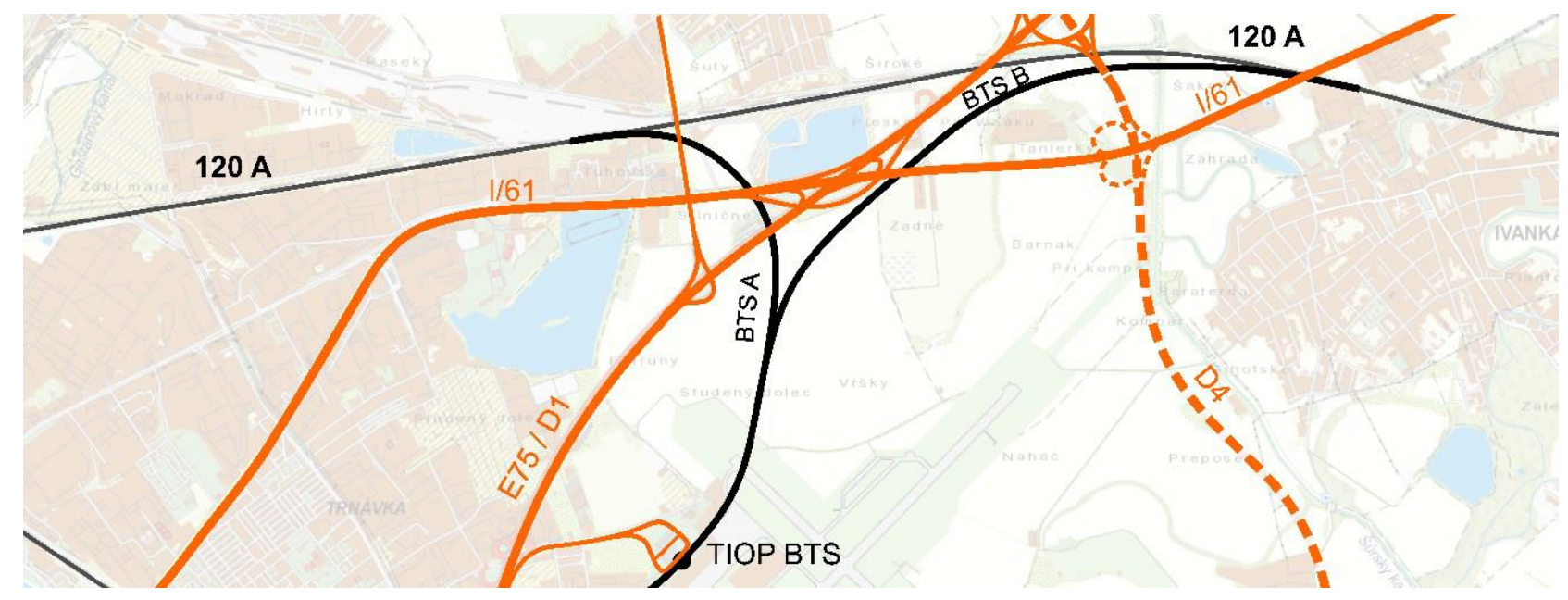

Obr. 4 Návrh napojenia TIOP BTS na trat' ŽSR 120A; zdroj: (Remeň, 2019)

Vizuálne znázornenie trasovania úseku BTS A znázorňuje mapa v mierke 1: 25000 na obrázku 4, kde sú zretel'né celkové priestorové možnosti vedenia tohto úseku. Priestorová kolízia nastáva v záhradkárskej oblasti pri Vajnorskom nadjazde a pri odpočívadle Zlaté Piesky. Trat' je vedená z úrovne terénu od miesta napojenia, tam kde je to možné, v zárezoch k letisku odkial' pokračuje až k TIOP BTS tunelom.

Celkové posúdenie prínosov, ale i negatívnych vplyvov vybudovania úseku BTS A je uvedené v tabul'ke 1, pričom nevýhody vznikajú najmä vo fáze výstavby, a v princípe sú negatívnym vplyvom pri výstavbe všetkých alternatív. Trvalým negatívnym účinkom je záber ornej pôdy v oblasti a d'alšie priestorové rozdelenie územia trat'ou vedenou zväčša v zárezoch. (ŽSR, 2019) 
Tab. 1 Posúdenie vplyvov výstavby trat’ového úseku BTS A; zdroj: (Remeň, 2019)

\section{Výhody trat'ového úseku BTS A}

Napojenie na hlavnú dvojkol'ajnú elektrifikovanú trat' (trat'. rýchlost' v súčasnosti do $120 \mathrm{~km}^{\mathrm{h}}{ }^{-1}$ )

Prebiehajúca modernizácia a elektrifikácia trati na rakúskej strane s trat'ovou rýchlost'ou 200 $\mathrm{km} \cdot \mathrm{h}^{-1}$

Elektrifikácia ŽST Devínska Nová Ves - štátna hranica vo fáze projektových príprav

Trasa priameho spojenia vedie pri tejto alternatíve cez frekventovaný prestupný uzol ŽST

Bratislava hl. st.

Možnost' priameho prepojenia letísk s najnižšími nákladmi na výstavbu

Trasovanie v minimálne zastavanej oblasti a s tým spojená technologická náročnost’ výstavby

Trat'ová rýchlost' tohto úseku minimálne $100 \mathrm{~km} \cdot \mathrm{h}^{-1}$

\section{Nevýhody trat'ového úseku BTS A}

Lokálne prepady maximálnej trat'ovej rýchlosti na súčasnej infraštruktúre až na $30 \mathrm{~km} . \mathrm{h}^{-1}$

Súčasné využitie kapacity infraštruktúry medzi ŽST Bratislava hl.st. - ŽST Devínska Nová Ves

Záber pol'nohospodárskej pôdy

Obmedzenia prevádzky počas výstavby na dôležitých cestných komunikáciách a hlavných t’ahoch Zvýšená hladina hluku a prašnosti pri výstavbe

V súčasnosti už plánovanou elektrifikáciou nadväzujúceho trat'ového úseku, prípadne pridaním druhej trat'ovej kol'aje a komplexnou modernizáciou po ŽST Devínska Nová Ves význam tejto trasy výrazne vzrastie, čím sa môže zaradit' $\mathrm{k}$ výhodám vybudovania trat'ového úseku BTS A. Strategický rozvoj dopravného uzla Bratislava, založený najmä na Štúdii realizovatel'nosti ŽSR z roku 2019, by tiež prispel k minimalizácii spomínaných nevýhod. Výhodnost' vybudovania tohto úseku môže vzrást’ v kombinácii $\mathrm{s}$ alternatívou napojenia úsekom BTS $C$, čím vznikne $v$ dopravnom uzle Bratislava možnost' použitia infraštruktúrnej "slučky" pre vlaky vedené do ŽST Bratislava Nové Mesto zo smeru Trnava a Malacky, bez nutnosti obiehat' v prípade zloženia vlaku z klasických súprav.

Obrázok 4 uvedený vyššie zobrazuje napojenie TIOP BTS trat’ovým úsekom označeným BTS B smerujúceho od ŽST Bernolákovo a napojenom na trat' ŽSR 120A v kilometri 67,500. Tento trat'ový úsek je zamýšl’aný ako dvojkol'ajný a elektrifikovaný, ktorý je vedený v úrovni terénu, pričom kríženie s cestnými komunikáciami D4 a I/61 je riešené mimoúrovňovo.

Trat'ový úsek BTS B sa v úrovni odpočívadla Zlaté Piesky napája na úsek BTS A odkial' budú spolu ako dvojkol'ajný trat'ový úsek vedené tunelom k TIOP BTS. Plánovaný trat’ový úsek BTS B je v rámci prepravy osôb na letisko opodstatnený a preto bude považovaný za rozvojový variant v rámci nadväzujúcich etáp výstavby železničnej infraštruktúry k napojeniu plánovaného TIOP BTS.

Tab. 2 Posúdenie vplyvov výstavby trat'ového úseku BTS B; zdroj: (Remeň, 2019)

\section{Výhody trat'ového úseku BTS B}

V kombinácii s trat'ovým úsekom BTS C vytvorí paralelnú trasu k trati ŽSR 120A

V kombinácii s úsekom BTS C vznikne možnost' spojit’ TIOP BTS, ŽST Bratislava Nové Mesto, ŽST

Bratislava hl. st., čím je možné zvýšit' ich atraktivitu a využitie v medzinárodnej i regionálnej preprave osôb

S úsekom BTS C vznikne infraštruktúrna "slučka" vhodná pre vlaky vedené do ŽST Bratislava Nové Mesto zo smeru Senec

\section{Nevýhody trat'ového úseku BTS B}

Záber pol'nohospodárskej pôdy

Obmedzenia počas výstavby ako pri BTS A

Navrhovaný trat'ový úsek BTS B v dĺžke 4,2 km má tiež opodstatnenie pri preprave osôb nielen na letisko a preto vypracovaná tabul'ka 2 dokumentuje vplyvy spôsobené vybudovaním práve tohto úseku, napriek tomu ide o rozvojový variant $\mathrm{v}$ rámci účelu budovania infraštruktúry. Najväčšie prínosy tento úsek 
vykazuje v kombinácii s trat’ovým úsekom BTS C, kde pri vhodnom trasovaní medzinárodných vlakov vznikne spojenie Budapešti, letiska pomocou TIOP BTS, mesta Bratislava a Prahy, pričom vzrastie potenciál ŽST Bratislava Nové Mesto, ako prestupného uzla aj v regionálnej doprave, či MHD. Podmienkou tohto pozitívneho vplyvu daných úsekov je zvýšenie kapacity trat'ového úseku ŽSR 127G medzi ŽST Bratislava Nové Mesto a ŽST Bratislava hl. st. pridaním druhej trat'ovej kol'aje. Toto odporúčanie podporuje aj štúdia realizovatel'nosti dopravného uzla Bratislava z roku 2019 na základe analýzy súčasného stavu.

\subsection{Napojenie na trat’ový úsek ŽSR 127C}

Ďalším vhodným miestom napojenia TIOP BTS na existujúcu železničnú infraštruktúru je trat'ový úsek 127C. Budovaniu železničnej infraštruktúry pre účely letiska sa venovala pozornost' v niekol'kých štúdiách. Dopravno-urbanistická štúdia projektu TEN-T 17 z roku 2009 predpokladala výstavbu železničnej infraštruktúry napojenej na trat'ový úsek ŽSR 127C v oboch spomínaných smeroch, pričom napojenie zo smeru ŽST Bratislava - ÚNS malo byt' realizované mostovou konštrukciou, kde trat' pred letiskom klesá a pokračuje v tuneli spolu s vetvou zo smeru ŽST Bratislava Nové Mesto k podzemnej stanici pri letisku. Myšlienky napojenia z tejto štúdie zostávajú zachované, pretože obe alternatívy napojenia nielen od ŽST Bratislava Nové Mesto, ale aj zo smeru ŽST Bratislava - ÚNS majú opodstatnenie s preukázatel'ným potenciálom. Tieto alternatívy sú kvôli jednoznačnému rozlíšeniu označené ako úseky BTS C a BTS D, a toto značenie a trasovanie daných úsekov prezentuje mapa v mierke $1: 25000$ na obrázku 5.

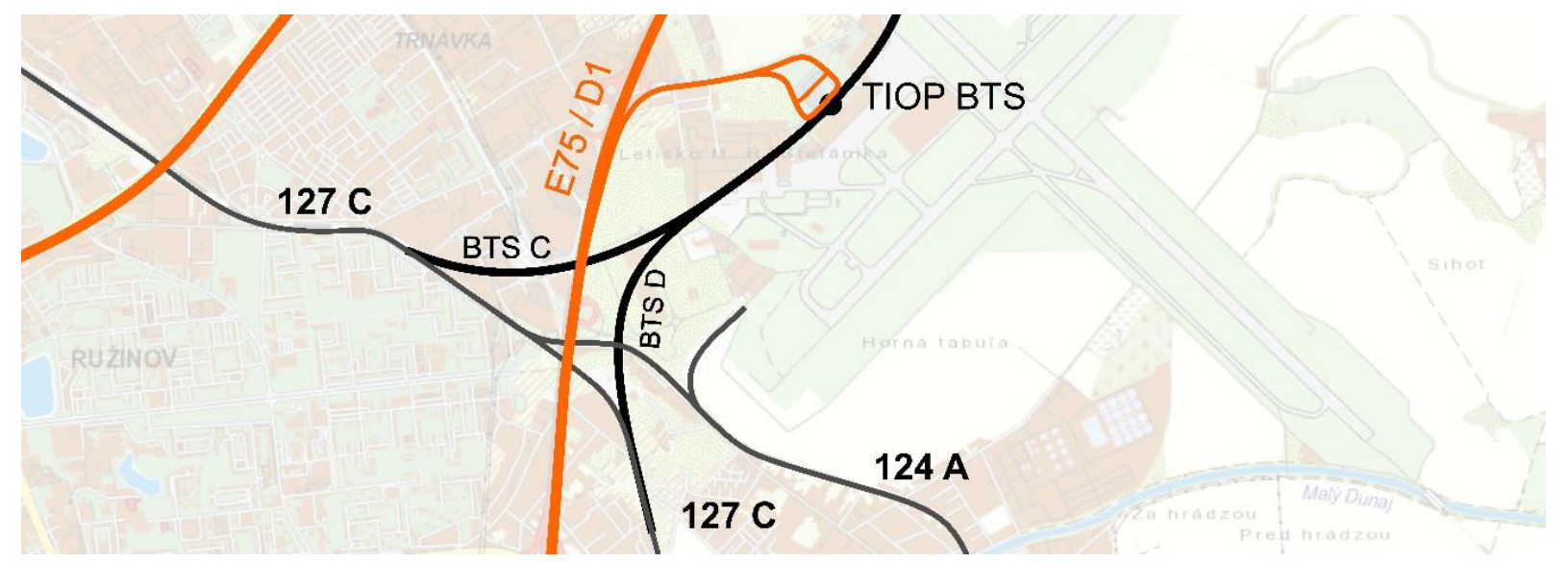

Obr. 5 Priestorový rádius možností umiestnenia prestupného bodu zo ŽD; zdroj: (Remeň, 2019)

Trat'ový úsek BTS C je vedený v celej dížke 2,3 km pod úrovňou terénu vzhl'adom najmä na rozsiahlu mestskú výstavbu v plánovanej trase. Pri súčasnej výstavbe s úsekom BTS B je vhodné tieto úseky budovat’ s dvomi trat'ovými kol'ajami, čím vznikne plnohodnotný a súbežný úsek s pôvodnou trat'ou ŽSR 120A s vyššie uvedenými výhodami. Pri samostatnej výstavbe bez uvažovania zmeny trasy niektorých vlakov osobnej dopravy z trate $120 \mathrm{~A}$ je možné s týmto úsekom uvažovat' ako jednokol'ajným. Pri oboch možnostiach by však miesto napojenia na trat' 127C malo reflektovat' na plánovaný rozvoj nielen tohto úseku ale i v tejto časti mesta paralelne vedenom trat'ovom úseku 124A do ŽST Podunajské Biskupice.

Rozvoj spomínaných existujúcich trat'ových úsekov a predovšetkým úseku 124A zvýšením kapacity, najmä pridaním druhej trat'ovej kol'aje odporúča vypracovaná štúdia realizovatel'nosti dopravného uzla Bratislava z roku 2019. V oblasti Vrakunskej cesty je okrem iného v pláne vybudovanie TIOP Ružinov výstavbou nástupíšt' a úpravou geometrickej polohy kol’ají. V rámci zvýšenia kapacity trate $124 \mathrm{~A} \mathrm{v}$ predmetnom medzistaničnom úseku je navrhovaná výstavba novej dopravne v podobe odbočky Ružinov, odporúčaná v každej alternatíve. (ŽSR, 2019)

Na tieto návrhy preto nadväzuje plánovaný úsek BTS C, ktorý je vhodné napojit’ na súčasnú železničnú infraštruktúru práve $\mathrm{v}$ plánovanej odbočke Ružinov, pričom trasovanie nutne nemusí zahŕňat' TIOP Ružinov vzhl'adom na charakter prepravy osôb na letisko. V tabul'ke 3 sú uvedené výhody a nevýhody výstavby úseku BTS C. 
Tab. 3 Posúdenie vplyvov výstavby trat'ového úseku BTS C; zdroj: (Remeň, 2019)

Výhody trat'ového úseku BTS C

V kombinácii s úsekom BTS B sú výhody zhodné

Možnost' priameho prepojenia letísk

Pri samostatnom budovaní trasa plánovaného spojenia zahrnie aj ŽST. Bratislava Nové Mesto

Nevýhody trat'ového úseku BTS C

Kapacita medzistaničného úseku ŽST Bratislava hl. st. - ŽST Bratislava Nové Mesto

Vyššia nákladová aj stavebná náročnost' oproti BTS A

Odlišnost' prínosov samostatného úseku BTS C oproti trat'ovému úseku BTS A spočíva v spôsobe trasovania plánovaného spojenia cez ŽST Bratislava Nové Mesto, pričom d'alšie výhody tieto alternatívy zdiel'ajú spoločne. Nevýhodou úseku je jeho vedenie pod úrovňou terénu v celej dĺžke pod zastavanou mestskou oblast'ou, čo značne navyšuje stavebné náklady aj celkovú náročnost' výstavby. Väčšinu existujúcich nevýhod trasovania plánovaného spojenia cez Marchegg taktiež tieto alternatívy BTS A a BTS C majú spoločné. Druhá spomínaná možnost' je navyše znevýhodnená obmedzujúcim úsekom ŽST Bratislava hl. st. - ŽST Bratislava Nové Mesto. Tento medzistaničný úsek je v súčasnosti kapacitne najvyt’aženejším úsekom železničného uzla Bratislava. (ŽSR, 2019)

Podmienkou vyrovnania vplyvov úsekov BST A a BTS C je teda dobudovanie druhej trat'ovej kol'aje v tomto obmedzujúcom úseku. Spôsob napojenia TIOP BTS z trat'ového úseku ŽSR 127C smerovaného na ŽST Bratislava - ÚNS znázorňuje obrázok 5, kde je zobrazený predmetný trat'ový úsek BTS D. Ten je od TIOP BTS vedený pod úrovňou terénu až k trat'ovému úseku 127C, kde sa v oblasti ulice Na piesku napája v kilometri 9,200. Trasovanie pod úrovňou terénu pod trat'ou 124A a Vrakunskou cestou bolo zvolené vzhl'adom na sklonové pomery. Jednokol'ajný úsek BTS D je plánovaný, zhodne s predchádzajúcimi, ako elektrifikovaný štandardnou napájacou sústavou $25 \mathrm{kV} 50 \mathrm{~Hz}$. Zobrazenie vplyvov výstavby trat'ového úseku BTS D v dĺžke 2,15 km znázorňuje tabul'ka 4.

Tab. 4 Posúdenie vplyvov výstavby trat’ového úseku BTS D; zdroj: (Remeň, 2019)

\section{Výhody trat'ového úseku BTS D}

Možnost' priameho prepojenia letiska BTS s viedenským letiskom

Existujúca nadväzujúca infraštruktúra je plne elektrifikovaná

Nevýhody trat'ového úseku BTS D

Technologicky a ekonomicky náročný úsek na výstavbu

Technický stav nadväzujúcej infraštruktúry po ŽST Bratislava - Petržalka

Uvedené nevýhody vybudovania samostatného úseku BTS D predstavujú najmä vysoké investičné náklady do budovania tohto úseku a modernizácie nadväzujúcej infraštruktúry po ŽST Bratislava - Petržalka. Ich elimináciou by tento plánovaný úsek výrazne zvýšil svoj význam. Ten by razantne tiež zvýšila aj plánovaná výstavba železničnej trate medzi stanicami Wien Flughafen a Bruck a. d. Leitha za účelom zvýšenia kapacity súčasnej Ostbahn medzi Viedňou a Budapešt'ou. Výstavbou tejto trate by bola stanica Wien Flughafen napojená na siet' TEN - T vysokovýkonnou trat'ou, čo prinesie možnost' upravit' trasovanie vlakov osobnej dopravy cez tento významný prestupný bod. (ÖBB, 2017)

Medzi nimi sú napríklad aj vlaky z linky medzi Wien hbf a ŽST Bratislava - Petržalka, ktoré by tak mohli byt' predížené po TIOP BTS. Vznikla by možnost' vytvorit' spojenie hlavnej stanice vo Viedni, letiska FWAG a letiska BTS. V prípade súčasnej realizácie výstavby úsekov BTS D a BTS A vznikne možnost' takéto spojenie predÍžit’ až na Bratislavskú hlavnú stanicu. Maximálnou možnost’ou návrhu železničného spojenia podmienenej existenciou infraštruktúry tvorenej úsekmi BTS A a BTS D je Bratislavsko - Viedenský okruh. 


\section{ZÁVER}

Skúmané alternatívy sa vzájomne nevylučujú a každý z týchto plánovaných úsekov predstavuje svoj osobitný prínos vzhl'adom na účel napojenia TIOP BTS. Synergický efekt kombinovania týchto trat'ových úsekov výrazne zvyšuje hodnotu ich inak samostatných prínosov. Preto je vhodné tieto plánované úseky považovat' skôr za jednotlivé etapy rozvoja železničnej infraštruktúry pri letisku BTS než samostatné alternatívy, pričom je potrebné ich klasifikovat' podl'a stanovenej prioritnej úrovne. Úroveň prioritného budovania predmetných úsekov zobrazuje tabul'ka 5, kde úroveň vychádza z upravenej analýzy manažmentu interného prostredia podniku doplnená o váhu jednotlivých faktorov.

Vzhl'adom na rozdielnost' vplyvov týchto faktorov na predmetné trat'ové úseky bola pri posudzovaní zvolená stupnica významnosti v rozsahu 1 - 10. Hodnotenie úseku pri konkrétnom faktore na stupnici 1 5, kde číslo 5 znamená najlepšie hodnotenie, je násobené váhou pri konkrétnom faktore tak, aby bol zohl'adnený jeho význam. Výsledný súčet bodov určí významnost' posudzovaných trat'ových úsekov k TIOP BTS. Dôraz bol pri vol'be stupnice kladený na náročnost' výstavby v porovnaní s okamžitým prínosom a najnižšími podmieňujúcimi požiadavkami na úpravu súčasnej infraštruktúry.

Tabul'ka 5. Kritické faktory priorizovania plánovaných úsekov napojenia TIOP BTS; zdroj: (autori)

\begin{tabular}{|c|c|c|c|c|c|c|c|c|c|c|}
\hline Hodnotenie úseku pri danom faktore & 1 & 2 & 3 & 4 & 5 & Váha & BTS A & BTS B & BTS C & BTS D \\
\hline \multicolumn{7}{|c|}{ 1. Atraktivita trat'. ús. napojenia TIOP BTS v rámci prepravy osôb } & 352 & 250 & 329 & 331 \\
\hline $\begin{array}{l}\text { Súčasný celkový potenciál využitia } \\
\text { úseku }\end{array}$ & B & & & $\begin{array}{l}\mathrm{A} \\
\mathrm{C} \\
\mathrm{D}\end{array}$ & & 10 & 40 & 10 & 40 & 40 \\
\hline $\begin{array}{l}\text { Výhl’adový celkový potenciál } \\
\text { využitia úseku }\end{array}$ & & & $\begin{array}{l}\text { A } \\
\text { C }\end{array}$ & $\begin{array}{l}\mathrm{B} \\
\mathrm{D}\end{array}$ & & 8 & 24 & 32 & 24 & 32 \\
\hline $\begin{array}{l}\text { Potenciál prepojenia letísk BTS a } \\
\text { FWAG }\end{array}$ & B & & & & $\begin{array}{l}\text { A } \\
\text { C } \\
\text { D }\end{array}$ & 8 & 40 & 8 & 40 & 40 \\
\hline Potenciál využitia úseku samostatne & B & & & $\mathrm{C}$ & A & 7 & 35 & 7 & 28 & 35 \\
\hline $\begin{array}{l}\text { Potenciál využitia úsekov v } \\
\text { kombinácii }\end{array}$ & & & & $\begin{array}{l}\mathrm{A} \\
\mathrm{D}\end{array}$ & $\begin{array}{l}\mathrm{B} \\
\mathrm{C}\end{array}$ & 5 & 20 & 25 & 25 & 20 \\
\hline \multicolumn{11}{|c|}{ 2. Technický stav nadväzujúcej infraštruktúry pri návrhu trasy spojenia letísk } \\
\hline Aktuálny celkový stav (el., zab-zar.) & & & A & $\begin{array}{l}\mathrm{B} \\
\mathrm{C} \\
\mathrm{D}\end{array}$ & & 5 & 15 & 20 & 20 & 20 \\
\hline $\begin{array}{l}\text { Vplyv aktuálne prebiehajúcich } \\
\text { projektov }\end{array}$ & $\begin{array}{l}B \\
D\end{array}$ & & & & $\begin{array}{l}\text { A } \\
\text { C }\end{array}$ & 2 & 10 & 2 & 10 & 2 \\
\hline Plánovaný celkový stav (el., zab-zar.) & & B & $\begin{array}{l}\text { C } \\
\text { D }\end{array}$ & A & & 5 & 20 & 10 & 15 & 15 \\
\hline Súčasná kapacita úsekov & $\mathrm{C}$ & $\begin{array}{l}\text { A } \\
\text { B } \\
\text { D }\end{array}$ & & & & 8 & 16 & 16 & 8 & 16 \\
\hline Plánovaná kapacita úsekov & & & $\mathrm{D}$ & $\begin{array}{l}\text { A } \\
\text { B } \\
\text { C }\end{array}$ & & 5 & 20 & 20 & 20 & 15 \\
\hline Súčasná technická rýchlost' & & & $\begin{array}{l}\text { C } \\
\text { D }\end{array}$ & $\begin{array}{l}\text { A } \\
\text { B }\end{array}$ & & 7 & 28 & 28 & 21 & 21 \\
\hline Plánovaná technická rýchlost’ & & & & $\mathrm{C}$ & $\begin{array}{l}\text { A } \\
\text { B } \\
\text { D }\end{array}$ & 4 & 20 & 20 & 16 & 20 \\
\hline \multicolumn{11}{|c|}{ 3.Výstavba trat'ových úsekov napojenia TIOP BTS } \\
\hline Technologická náročnost’ výstavby & $\begin{array}{l}\mathrm{C} \\
\mathrm{D}\end{array}$ & & & B & A & 7 & 35 & 28 & 7 & 7 \\
\hline Záber pôdy & & $\begin{array}{l}\text { A } \\
B\end{array}$ & & $\mathrm{D}$ & $\mathrm{C}$ & 7 & 14 & 14 & 35 & 28 \\
\hline Trvalý vplyv úseku na okolie & & B & A & $\begin{array}{l}\mathrm{D} \\
\mathrm{C}\end{array}$ & & 5 & 15 & 10 & 20 & 20 \\
\hline
\end{tabular}


Analyzované vplyvy a účinky výstavby týchto trat'ových úsekov z TIOP BTS napojených na siet' ŽSR vykazujú, podl’a tabul'ky 5 rôznu hladinu významnosti pri súčasnej podobe infraštruktúry, pričom sa tento pomer výrazne obmení v rámci uvažovania s plánovaným rozvojom existujúcej infraštruktúry. Vzhl’adom k pomeru náročnosti výstavby a okamžitých prínosov po vybudovaní samostatného úseku sa prioritným v rámci základnej etapy výstavby železničnej infraštruktúry k letisku BTS stáva trat'ový úsek BTS A. Významné opodstatnenie získa úsek BTS D po vybudovaní trate na rakúskej strane medzi stanicou Wien Flughafen a Bruck an der Leitha. V súčasnosti úsek BTS A sa svojimi prínosmi neprekoná, najmä kvôli technológii výstavby a nutnosti zaviest' nové vlaky osobnej dopravy, pretože stanice Wien hbf a Wien Flughafen v súčasnosti nie je možné obslúžit' priamo, podobne ako pri BTS A, pričom jazda úvrat'ou spôsobuje časové straty. Preto je úsek BTS D považovaný za prvú rozvojovú etapu základnej schémy železničnej infraštruktúry v okolí letiska BTS. Spolu s týmto úsekom je rovnako pod úrovňou terénu plánovaný aj úsek BTS C, ktorý by s BTS D mal byt' budovaný súčasne. Najmä pri podmienke vybudovania druhej trat'ovej kol'aje medzistaničného úseku ŽSR 127G. Významovo prepojeným je s BTS C uvažovaný úsek BTS B, ktorý je v rámci etáp rozvoja opodstatnený až vo finálnej fáze, ktorá zavŕši celkovo 11,7 km nových tratí napojených na siet' ŽSR v rámci dopravného uzla Bratislava.

Na základe analýzy možností napojenia letiska BTS na železničnú siet' ŽSR je v počiatočnej fáze výstavby potrebné vybudovat' pod úrovňou terénu v oblasti parkoviska podzemnú železničnú stanicu, ktorá sa stane súčast'ou terminálu integrovanej osobnej prepravy. Napojená na siet' ŽSR bude v prvej etape výstavby jednokol’ajným úsekom v celkovej dížke 3,342 kilometra a elektrifikovaným striedavou napájacou napät'ovou sústavou $25 \mathrm{kV}, 50 \mathrm{~Hz}$ vrátane uvedenej železničnej stanice. Tento úsek s trat'ovou rýchlost'ou do $160 \mathrm{~km} . \mathrm{h}^{-1}$ bude vedený z TIOP BTS l'avým oblúkom polomeru $1200 \mathrm{~m}$ a prevýšením kol'ajnicových pásov $126 \mathrm{~mm}$ do priameho úseku dížky 715 metrov. Na tento priamy úsek nadväzuje druhý, opät' l'avý, oblúk s maximálnou trat'ovou rýchlost'ou zníženou na $100 \mathrm{~km} \cdot \mathrm{h}^{-1}$, polomerom $810 \mathrm{~m}$ a prevýšením $88 \mathrm{~mm}$. Zaústený je do trate ŽSR $120 \mathrm{~A}$ v kilometri 62,797 v obvode ŽST Bratislava -Vajnory.

„Táto práca bola podporená Agentúrou na podporu výskumu a vývoja na základe Zmluvy č. APVV-190444."

\section{Literatúra}

Remeň, L. 2019. Návrh železničného spojenia medzi letiskami M. R. Štefánika - Airport Bratislava, a. s. a Flughafen Wien AG. [Diplomová práca], Žilinská univerzita v Žiline, Žilina. EDIS Žilina.

Čechovič, L., Gerhátová, Z., Kendra, M. 2020. Proposal transport services airport Leoš Janáček Ostrava / Návrh dopravnej obsluhy letiska Leoša Janáčka Ostrava. In: Transport technic and technology [electronic]. Roč. 16, č. 2 (2020), s. 16-20.

Černá, L., Lupták, V., Šulko, P., Blaho, P. 2018. Capacity of main railway lines - analysis of methodologies for its calculation / Kapacita hlavných železničných tratí - analýza metodík ich stanovenia. In: Naše More = Our Sea: znanstveni časopis za more i pomorstvo: international Journal of Maritime Science \& Technology (online). - Roč. 65, č. 4 (2018), s. 213-217.

Mako, P., Dávid, A., Böhm, P., Savu, S. 2021. Sustainable transport in the Danube region / Udržatel'nost' dopravy v dunajskom regióne. In: Sustainability [electronic]. Roč. 13, č. 12 (2021), s. 1-21. Dostupné online: https://www.mdpi.com/2071-1050/13/12/6797

Zitrický, V., Lupták, V., Stopka, O., Stopková, M. 2020. Comparative analysis in terms of environmental impact assessment between railway and air passenger transport operation: a case study / Komparatívna analýza environmentálneho vplyvu medzi železnicou a leteckou prevádzkou $\mathrm{v}$ osobnej doprave : prípadová štúdia. In: International Journal of Sustainable Aviation [print, electronic]. Roč. 6, č. 1 (2020), s. 21-35.

BTS.AERO, 2012. Výročná správa letiska M. R. Štefánika - Airport Bratislava, a.s. [Online]. Dostupné z: < https://www.bts.aero/o-letisku/press/rocne-spravy/ > [cit.: 2021, 3. október]. 
BTS.AERO, 2018. Výročná správa BTS. [Online]. Dostupné z: < https://www.bts.aero/downloads/rocnespravy/rocna-sprava-2018.pdf?u=1> [cit.: 2021, 1. október].

ÖBB, 2017. Enviromentálna správa. Zmena celospolkovej hlavnej dopravnej siete, Vyhlásenie železničnej dráhy „Viedeň - Flughafen Wien (letisko Viedeň) -Bruck / Leitha -štátna hranica pri obci Nickelsdorf” za vysokovýkonnú trasu. [Online]. Dostupné z: https://www.bmk.gv.at/dam/jcr:3dd3b444-2223-426c-a4d1a23ebfb9dacb/umweltbericht_slowakisch.pdf [cit.: 2021, 1. október].

ŽSR, 2019. Štúdia realizovatel’nosti - ŽSR, dopravný uzol Bratislava. 2019. [Online]. Dostupné z: < https://www.zsr.sk/modernizacia-trati/studie-realizovatelnosti/uzol-bratislava.html > [cit.: 2021, 4. október]. 